УДК 544.032.2

\title{
ПЕРСПЕКТИВА ВИКОРИСТАННЯ СПОСОБУ ДИСКРЕТНО-ІМПУЛЬСНОГО ВВЕДЕННЯ ЕНЕРГІЇ ДЛЯ НЕЙТРАЛІЗАЦІЇ КИСЛИХ ВОДНИХ РОЗЧИНІВ
}

\author{
Яроцький С.М. ${ }^{1}$, Целень Б.Я. ${ }^{2}$, канд. техн. наук
}

${ }^{1}$ Національний технічний університет Украӥни «Київський політехнічний інститут», просп. Перемоги, 37, Київ, 03056, Україна

${ }^{2}$ Інститут технічної теплофізики НАН України, вул. Желябова, 2а, Київ, 03680, Україна

\begin{abstract}
Обгрунтовано ефективність впливу способу дискретноімпульсного введення енергії на водні розчини. Розглянуто механізми радикального розпаду води 3 утворенням пероксиду водню під впливом кавітації, а також роль гідрокарбонат-іонів та іонів заліза, що містяться у воді на зміну іiі $\mathrm{pH}$. Запропоновано нові напрямки застосування дискретно-імпульсного введення енергії 3 використанням роторно-імпульсного апарата типу ротор-статор-ротор.
\end{abstract}

Бібл. 7, табл. 1 , рис. 1.
Обоснована эффективность влияния метода дискретно-импульс ного ввода энергии на водные растворы. Рассмотрены механизмы радикального распада воды с образованием пероксида водорода под влиянием кавитации, а также роль гидрокарбонат-ионов и ионов железа содержащихся в воде на изменение ее $\mathrm{pH}$. Предложены новые направления применения дискретно-импульсного ввода энергии с использованием роторноимпульсного аппарата типа роторстатор-ротор.
Efficiency of discrete-pulse input of energy effect to aqueous solutions was validated. Mechanism of water radical decay and hydrogen peroxide formation under cavitation effect, the role of bicarbonates and iron ions contained in water to change its $\mathrm{pH}$ were considered. New ways using discrete-pulse input of energy from rotor-pulsation apparatus type such as rotor-stator-rotor were offered.

Ключові слова: кавітація, дискретно-імпульсне введення енергії, нейтралізація, водні розчини, пероксид водню, гідрокарбонат-іони.

C - концентрація;

$\mathrm{e}_{\text {аq }}$ - гідратований електрон;

$\mathrm{pH}$ - водневий показник;

$\mathrm{CO}_{2}$ - вуглекислий газ;

$\mathrm{HCO}_{3}^{-}$- гідрокарбонат-іон;

$\mathrm{HO}_{2}^{-}$- гідропероксид-іон;

$\mathrm{H}^{+}-$іон водню;

$\mathrm{H}^{\circ}$ - радикал водню;

$\mathrm{H}_{2}$ - водень;

\section{Bcmyn}

Вода є найголовнішим ресурсом на планеті. Iіï використовують всюди, починаючи від побутових потреб та закінчуючи промисловістю. Тому цілком очевидно, що недостатній запас прісної води може призвести до незворотних наслідків. Розвиток промисловості та господарської діяльності спричиняє забруднення все більших об'ємів води. Неможливість самоочищатися перетворює водойми на стічні канали.

Водоспоживання в Україні поки-що не
$\mathrm{H}_{2} \mathrm{O}$ - вода;

$\mathrm{H}_{2}^{2} \mathrm{O}_{2}$ - пероксид водню;

$\mathrm{OH}^{-}$- гідроксид-іон;

$\mathrm{OH}^{\circ}$ - гідроксильний радикал;

$\mathrm{O}_{2}$ - кисень;

$\mathrm{O}_{2}^{-}-$супероксидний радикал;

$\mathrm{O}^{2-}-$ пероксид;

ДІВЕ - дискретно-імпульсне введення енергії.

перевищує допустимого рівня відносно наявних водних ресурсів, проте в багатьох південних районах відчутний дефіцит води. Тому все більшого значення набуває проблема розумного, раціонального використання прісної води i, особливо, очищення стічних вод, а також одночасна організація замкнених систем зворотного водоспоживання в промисловості та сільському господарстві. При використанні в промисловості вода забруднюється речовинами органічного та мінерального походження. Таку воду прийнято називати стічною водою. 
Практика свідчить, що найбільшу небезпеку для навколишнього середовища створюють кислі стічні води. Вони визначаються активністю іонів водню, яка характеризується $\mathrm{pH}$. Цей показник надзвичайно важливий для біохімічних процесів, швидкість яких може істотно знижуватись при різкій зміні $\mathrm{pH}$ середовища. Стічні води, що надходять на споруди очищення, повинні мати значення $\mathrm{pH}$ в межах $6,5 \ldots 8,5$, тому промислові стічні води (кислі або лужні) повинні бути нейтралізовані перед скиданням у водовідвідну мережу, щоб запобігти iii руйнуванню. Міські стічні води зазвичай мають низьку лужну реакцію середовища $(\mathrm{pH}=7,2 \ldots 7,8)[1]$.

Екологічна обстановка в Україні та у всьому світі в цілому спонукає до ретельного контролю якості води. Через це хімічні підприємства змушені скидати стічні води лише належної якості, тобто ті, які відповідають санітарним нормам. Проте, очищення води потребує спеціального обладнання і додаткових витрат. Тому пошук нових, альтернативних методів очищення стічних вод на сьогоднішній день $\epsilon$ дуже актуальним.

\section{Постановка проблеми}

В поняття «стічні води» входять різні за походженням, складом, фізико-хімічними властивостями води, які використовувались людиною для різних побутових і технологічних потреб. Тому для очищення води потрібно декілька стадій та методів в залежності від їі походження, характеру забруднення та ін. В рамках проведеного дослідження розглядали стічні води, що характеризуються кислою реакцією середовища.

Відомі на сьогодні способи нейтралізації стічних вод або застаріли, або мають ряд недоліків. Найпоширеніші методи призводять до таких проблем, як утворення гіпсу, що забруднює трубопроводи та забиває фільтри (внаслідок взаємодії сірчаної кислоти i вапняного молока); складність регулювання рівномірної подачі відпрацьованих вод через наявність додаткових реагентів та місцевих умов; забруднення продуктами реакції тощо [2].

Це спонукає до пошуку альтернативних, екологічно чистих методів нейтралізації з низькими енерговитратами, які позбавлені зазначених вище недоліків.

\section{Літературний огляд}

Для нейтралізації кислих водних розчинів у більшості випадків застосовують методи, що передбачають введення хімічних реагентів, що призводить до появи стічних вод, забруднених продуктами реакції нейтралізації. Застосовування фізичних методів дозволить знизити екологічне навантаження на оточуюче середовище. Одним зі способів, в яких реалізовані фізичні методи впливу на оброблюване середовище, є спосіб ДІВЕ.

Запропонований спосіб відноситься до методів спрямованого дискретного енергетичного впливу, що дозволяє акумулювати в робочому об'ємі рідкого середовища теплову або потенціальну енергію, а потім трансформувати iï в кінетичну. В основу способу покладено комплекс таких фізичних явищ і ефектів, як спадання i зростання тиску, гідравлічний удар, механізми зсувних напружень, звукові та ультразвукові ефекти, мікрозакипання, кавітація, ефекти турбулентності, вихроутворення, сонолюмінісценція, поляризація частинок, локальне нагрівання та інші явища. Дані явища базуються на просторовій і тимчасовій локалізації введеної енергії. В цих процесах реалізуються надвисока щільність потоків енергії і маси на міжфазних поверхнях, що обумовлено локальним характером процесу [3].

Одним з основних факторів впливу на гетерогенне рідке середовище є кавітація, що призводить до розриву крапельної рідини під дією розтягувальних напружень, які виникають при розрідженні в певній їі точці. При цьому утворюються порожнини - кавітаційні бульбашки, які заповнені парою, газом або їх сумішшю. Відповідно, розрив рідини обумовлений зміною характеристик полів швидкостей і тисків.

Кавітаційні бульбашки утворюються в тих місцях, де тиск в рідині стає нижчим від деякого критичного значення тиску. Якщо тиск знижується внаслідок зростання місцевих швидкостей потоку рідини - виникає гідродинамічна кавітація, якщо зниження тиску викликане проходженням акустичних хвиль - 
акустична.

Раніше кавітація розглядалась лише як негативне явище, оскільки через так звану кавітаційну ерозію руйнуються робочі поверхні. Але на теперішній час кавітація знаходить дедалі ширше застосування в різних технологічних процесах. Хоча це явище доволі нестабільне i його складно контролювати, можна створити відповідні умови для його утворення. Найпростіший метод створення штучної кавітації - подача повітря чи іншого газу в розріджену зону рідини. Також штучну кавітацію можна створювати на поверхнях різної форми: крилах, тілах обертання, гребних гвинтах тощо.

Для створення на таких поверхнях зони розрідження передбачають місцеві конструктивні зміни іiі форми у вигляді виступів (кавітаторів). В лабораторних умовах для ініціювання кавітації використовують вдування повітря, проте для утворення природної кавітації потрібні великі швидкості рідини. Крім механічного впливу на поверхню, під час кавітації відбуваються різні фізико-хімічні процеси. При експериментальному дослідженні перебігу процесу кавітації в низькочастотних звукових полях була виявлена аналогія за фізико-хімічними ефектами між низькочастотною та ультразвуковою кавітацією [4].

Модель фізико-хімічних процесів, що відбуваються в кавітаційній бульбашці і прилеглому до неї об'ємі рідини, описується наступним чином. У кавітаційну порожнину можуть проникати пари води, розчинені гази, а також речовини 3 високою пружністю пари і не можуть проникати іони або молекули нелетких розчинених речовин. Під час перебігу кавітації виникають високі локальні мікромасштабні значення температури (до 10000 К) і тиску (до 100 МПа), тому газоподібні молекули води руйнуються як при піролізі, утворюючи радикальні високоактивні частинки, а також гідроксильні радикали [5]:

$$
\mathrm{H}_{2} \mathrm{O} \rightarrow \mathrm{HO}^{\circ}+\mathrm{H}^{\circ}
$$

утворення яких у воді визначається методом «спінових пасток» та хемілюмінесцентним методом.

Раніше вважалось, що первинні радикальні продукти розщеплення води при дії кавітації одні і ті ж $-\mathrm{H}^{\circ}$ i $\mathrm{OH}^{\circ}$. Проте численні дослідження радіаційно-хімічних реакцій призвели до відкриття нової активної частинки гідратованого електрона е ${ }_{\text {aq }}^{-}$. Виникає питання: чи не утворюються гідратовані електрони і при кавітації, і як це може вплинути на величину $\mathrm{pH}$ ? Молекули води і розчинений в ній газ під дією кавітації зазнають наступних перетворень [6]:

$$
\begin{gathered}
\mathrm{H}_{2} \mathrm{O} \rightarrow \mathrm{OH}^{\mathrm{o}}+\mathrm{H}^{\mathrm{o}} ; \\
\mathrm{H}^{\mathrm{o}}+\mathrm{H}^{\mathrm{o}} \rightarrow \mathrm{H}_{2} ; \\
\mathrm{OH}^{\mathrm{o}}+\mathrm{OH}^{\mathrm{o}} \rightarrow \mathrm{H}_{2} \mathrm{O}_{2} ; \\
\mathrm{OH}^{\mathrm{o}}+\mathrm{H}_{2} \rightarrow \mathrm{H}_{2} \mathrm{O}+\mathrm{H}^{\mathrm{o}} ; \\
\mathrm{H}^{\mathrm{o}}+\mathrm{OH}^{-} \rightarrow e_{a q}^{-}+\mathrm{H}_{2} \mathrm{O} ; \\
e_{a q}^{-}+\mathrm{H}^{+} \rightarrow \mathrm{H}^{\mathrm{o}} ; \\
e_{a q}^{-}+\mathrm{O}_{2} \rightarrow \mathrm{O}_{2}^{-} .
\end{gathered}
$$

Утворені хімічно активні радикали розщеплення води взаємодіють з іншими компонентами розчину змінюючи його властивості. Швидкість та напрямок хімічних реакцій значною мірою залежать від природи газоподібних речовин, що містяться в розчині або утворюються як побічні продукти реакції. Високоактивні частинки, що виникають в бульбашці після переходу в розчин після сольватації, реагують 3 розчиненими в ньому речовинами. На цій стадії на хід процесу можуть впливати практично тільки хімічно активні гази - кисень і водень.

Зрештою, вплив кавітації на утворення високоактивних частинок (іонів, радикалів) у водних розчинах зводиться до єдиного процесу - розщеплення молекул води в кавітаційних бульбашках. Незалежно від природи розчинених речовин, кавітація діє на одну речовину - на воду, а радикали та інші високоактивні частинки, які при цьому утворюються, вступають в реакцію з розчиненими речовинами, що призводить до зміни фізико-хімічних властивостей розчину: зміни $\mathrm{pH}$, електропровідності, числа вільних іонів і активних радикалів, а також структуризації і активації молекул.

\section{Основна частина}

В Інституті технічної теплофізики НАН України проведено низку експериментальних досліджень 
впливу кавітації на зміну $\mathrm{pH}$ кислих водних розчинів. Кавітаційні процеси реалізовувались за допомогою роторно-імпульсного апарата типу ротор-статор-ротор (рис. 1) шляхом проходження рідини по замкнутому контуру, абсолютний тиск в якому підтримувався вакуумним насосом на рівні приблизно 0,1 атм.

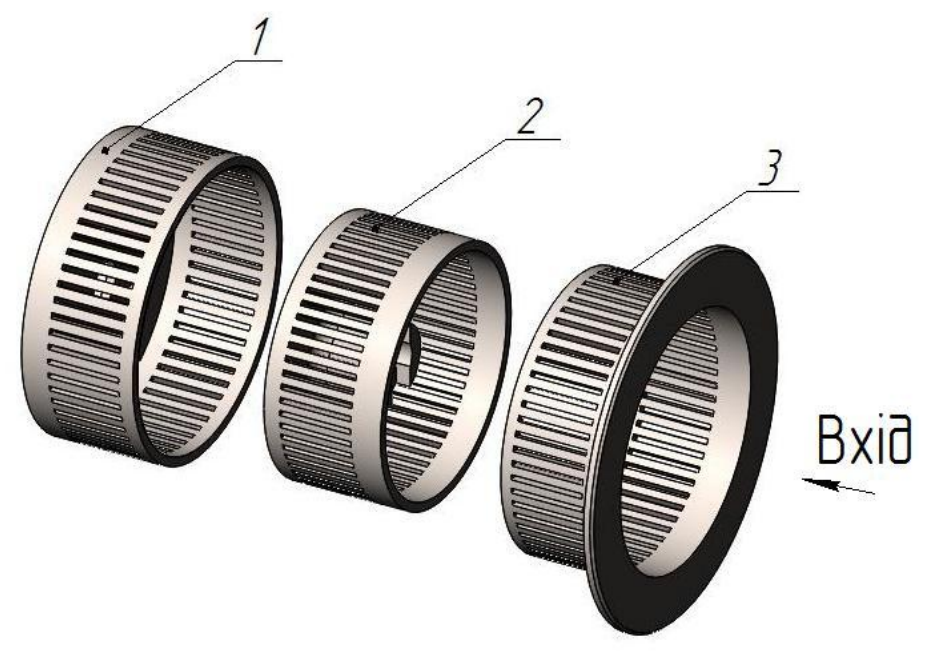

Рис. 1. Робоча частина роторно-імпульсного апарата:

1 -ротор зовнішній; 2 -ротор внутрішній; 3 -статор.

Досліди проводились на розчинах органічних і неорганічних кислот. Для приготування розчину використовували дистильовану і водопровідну воду. Введення кислоти у воду проводили за півгодини до початку обробки розчину. Тривалість обробки становила 8 хв. в режимі рециркуляції 16,5 л розчину при продуктивності 2 т/год. Проби розчину відбирались в скляні колби перед його обробкою, після 2, 4, і 8 хв. обробки і зберігались відкритими без впливу прямого сонячного світла. Вимірювання значень рН і температури проб здійснювали портативним рН-метром Hanna Instruments HI8424. Аналіз вмісту гідрокарбонатів у розчині проводили в лабораторії абсорбції та іонного обміну наукововиробничого об’єднання «Екософт». Концентрація пероксиду водню визначалась методом титрування розчином перманганату калію за стандартною методикою.

Під час обробки кислих розчинів на основі водопровідної води спостерігалось зростання величини $\mathrm{pH}$, причому найбільша швидкість зміни $\mathrm{pH}$ спостерігалась на протязі 2 хв. обробки. В розчинах, приготовлених на дистильованій воді, суттєвої зміни величини $\mathrm{pH}$ не спостерігалось.

В таблиці 1 наведено динаміку зміни $\mathrm{pH}$ розчину сірчаної кислоти у водопровідній воді до і після обробки, а також необробленої водопровідної води. Концентрація кислоти в розчині становила $0,7 \cdot 10^{-3}$ моль/л.

Швидкість зростання температури розчину становила приблизно $3^{\circ} \mathrm{C} / \mathrm{xв}$. протягом всього часу обробки. В таблиці показана температура проб, яка вимірювалась вже після обробки одночасно 3 вимірюванням $\mathrm{pH}$ розчину.

Результати аналізу на вміст гідрокарбонатів показали, що в розчині, обробленому протягом 8 хв., вміст гідрокарбонатів зменшився з 0,92 до 0,56 моль-екв/л порівняно 3 необробленим розчином. Отримане кінцеве значення величини $\mathrm{pH}$ розчину потрапляє в межі допустимих значень для стічних вод. Це дозволяє відмовитись від процесу попередньої нейтралізації з використанням реагентів перед скиданням у водовідвідну мережу.

Також визначався вміст пероксиду водню 3 метою визначення інтенсивності впливу кавітаційних явищ на оброблюване середовище. Результати аналізу показали незначне підвищення його вмісту після обробки з 0,0200 моль/л до 0,0225 моль/л.

\section{Обробка результатів досліджень}

Для оцінки впливу на рідину обробки способом ДІВЕ враховували також зміну величини $\mathrm{pH}$ в необробленій водопровідній воді, що на протязі 12 діб зріс з 6,96 до 8,18. Підвищення величини 
pH можна пояснити перебігом окисно-відновних реакцій в присутності пероксиду водню, який в незначній кількості наявний у водопровідній воді. Зростання величини $\mathrm{pH}$ зі збільшенням терміну зберігання спостерігалось також у всіх пробах 3 розчином - як обробленого так і необробленого, що також пояснюється реакціями розпаду пероксиду водню.

Підвищення величини $\mathrm{pH}$ розчину при його обробці зумовлене низкою явищ, що ініціюються способом дискретно-імпульсного введення енергії. Висунуто гіпотезу, що частково описує механізм перебігу процесу зміни величини рН кислих водних розчинів під впливом кавітації. Внаслідок практично відсутньої зміни величини рН при обробці кислого розчину, приготовленого на дистильованій воді, та суттєвого підвищення рН кислого розчину, приготовленому на водопровідній воді, можна припустити, що зростання величини $\mathrm{pH}$ залежить від складу розчинника.

Табл. 1. Динаміка зміни $\mathrm{pH}$ розчину сірчаної кислоти у водопровідній воді до і після обробки, а також необробленої водопровідної води

\begin{tabular}{|c|l|c|c|c|c|c|c|}
\hline \multirow{2}{*}{$\begin{array}{c}\text { № } \\
\text { злп }\end{array}$} & \multicolumn{1}{|c|}{$\begin{array}{c}\text { Найменування } \\
\text { проби }\end{array}$} & \multicolumn{3}{|c|}{ рН проби } & \multicolumn{3}{|c|}{ Температура проби, ${ }^{\circ} \mathrm{C}$} \\
\cline { 2 - 8 } & $\begin{array}{c}\text { В день } \\
\text { експерименту }\end{array}$ & $\begin{array}{c}\text { Через } 2 \\
\text { доби }\end{array}$ & $\begin{array}{c}\text { Через } 12 \\
\text { діб }\end{array}$ & $\begin{array}{c}\text { В день } \\
\text { експерименту }\end{array}$ & $\begin{array}{c}\text { Через 2 } \\
\text { доби }\end{array}$ & $\begin{array}{c}\text { Через } 12 \\
\text { діб }\end{array}$ \\
\hline 1 & $\begin{array}{l}\text { Вода водопровідна } \\
\text { необроблена }\end{array}$ & 6,96 & 7,92 & 8,18 & 13,6 & 19,3 & 13,6 \\
\hline 2 & $\begin{array}{l}\text { Розчин } \\
\text { необроблений }\end{array}$ & 5,91 & 6,72 & 7,05 & 16,6 & 20,0 & 13,7 \\
\hline 3 & $\begin{array}{l}\text { Розчин, оброблений } \\
\text { на протязі 2 хв. }\end{array}$ & 6,68 & 7,07 & 7,27 & 20,2 & 20,0 & 13,6 \\
\hline 4 & $\begin{array}{l}\text { Розчин, оброблений } \\
\text { на протязі 4 хв. }\end{array}$ & 6,86 & 7,38 & 7,36 & 21,5 & 19,9 & 13,5 \\
\hline 5 & $\begin{array}{l}\text { Розчин, оброблений } \\
\text { на протязі 8 хв. }\end{array}$ & 7,11 & 7,53 & 7,43 & 24,9 & 19,8 & 13,6 \\
\hline
\end{tabular}

Гіпотеза грунтується на наявності гідрокарбонат-іонів у водопровідній воді. Внаслідок високих локальних значень температури i тиску в кавітаційних бульбашках утворюються високоактивні іони та радикали. Іон водню взаємодіє з гідрокарбонат-іоном утворюючи молекули води та діоксиду вуглецю:

$$
\mathrm{H}^{+}+\mathrm{HCO}_{3}^{-} \rightarrow \mathrm{H}_{2} \mathrm{O}+\mathrm{CO}_{2} \uparrow \text {. }
$$

Зниження вмісту іонів водню зворотнопропорційним чином впливає на величину $\mathrm{pH}$. Теоретичний розрахунок зміни величини $\mathrm{pH}$ проводили на основі отриманих результатів обробки розчину сірчаної кислоти у водопровідній воді. Виміряна величина $\mathrm{pH}$ розчину перед його обробкою становила 4,82, а концентрація гідрокарбонат-іонів $3,605 \cdot 10^{-6}$ моль/л. Відомо, що величина $\mathrm{pH}$ виражається через концентрацію іонів водню

$$
p H=-\log C\left(\mathrm{H}^{+}\right) .
$$

Таким чином, виміряна величина рН показує, що вміст іонів водню в розчині становить

$$
C\left(\mathrm{H}^{+}\right)_{\text {п }}=10^{-p H}=10^{-4,82}=1,514 \cdot 10^{-5} \text { моль/л . }
$$

Так як на один іон водню припадає один гідрокарбонат-іон, то концентрація іонів водню зменшиться пропорційним чином відносно зменшення концентрації гідрокарбонат-іонів:

$$
\begin{gathered}
C\left(\mathrm{H}^{+}\right)_{\mathrm{K}}=C\left(\mathrm{H}^{+}\right)_{\text {п }}-C\left(\mathrm{HCO}_{3}^{-}\right)_{\Pi}= \\
=1,514 \cdot 10^{-5}-0,3605 \cdot 10^{-5}=1,153 \cdot 10^{-5} \text { моль } / л .
\end{gathered}
$$

Обчисленому значенню вмісту іонів водню в розчині відповідає величина $\mathrm{pH}$ розчину

$$
p H=-\log C\left(\mathrm{H}^{+}\right)_{\mathrm{\kappa}}=-\log 1,153 \cdot 10^{-5}=4,94 .
$$


Результат розрахунку показує, що розраховане значення величини $\mathrm{pH}$ змінилось лише на 0,1 тоді як на практиці - на 1,5. Слід також зазначити, що розрахунок враховує вступання в реакцію всіх гідрокарбонат-іонів, тоді як на практиці вступає лише половина. Отже, на підвищення $\mathrm{pH}$ розчину впливають і інші механізми.

Окисно-відновні реакції з участю пероксиду водню можна інтенсифікувати за допомогою методу ДІВЕ. Розпад пероксиду водню відбувається під дією різних фізико-хімічних впливів, до яких також відноситься і кавітація. Молекула пероксиду водню при цьому здатна розпадатись, утворюючи гідроксильні радикали [7]:

$$
\mathrm{H}_{2} \mathrm{O}_{2} \rightarrow 2 \mathrm{OH}^{\circ}
$$

Гідроксильні радикали мають високу реакційну здатність і тому існують лише на протязі короткого проміжку часу. Утворені радикали одразу взаємодіють майже зі всіма органічними та неорганічними речовинами, що присутні у воді. Найпоширенішим механізмом взаємодії гідроксильного радикалу є «відривання» водню від органічних сполук з утворенням води та органічного радикалу. Органічні радикали стабільніші i, відповідно, мають довший час існування. Проте і ці радикали взаємодіють 3 іншими речовинами утворюючи органічні сполуки.

На прикладі розкладанням пероксиду водню можна пояснити зменшення вмісту гідрокарбонатів у розчині після його обробки. Відновлення гідроксильних радикалів може відбуватись за наступною схемою:

$$
\mathrm{OH}^{\mathrm{o}}+\mathrm{HCO}_{3}^{-} \rightarrow \mathrm{HCO}_{3}^{\mathrm{o}}+\mathrm{OH}^{-} .
$$

В цій реакції активність гідроксильних радикалів виконує роль лімітуючого фактору. У водопровідній воді концентрація гідроксильних радикалів становить приблизно $10^{-17} \ldots 10^{-15}$ моль/л, тоді як під впливом кавітації вона значно збільшується, призводячи до підвищення $\mathrm{pH}$.

Крім гідрокарбонатів у воді міститься багато інших речовин, 3 якими може взаємодіяти гідроксильний радикал. Каталізатором такої взаємодії можуть бути іони заліза [8]:

$$
\begin{gathered}
\mathrm{Fe}^{3+}+\mathrm{HO}_{2}^{-} \rightarrow \mathrm{Fe}^{2+}+\mathrm{HO}_{2}^{\mathrm{o}} ; \\
\mathrm{Fe}^{2+}+\mathrm{H}_{2} \mathrm{O}_{2} \rightarrow \mathrm{Fe}^{3+}+\mathrm{OH}^{\mathrm{o}}+\mathrm{OH}^{-} \\
\mathrm{Fe}^{2+}+\mathrm{OH}^{\mathrm{o}} \rightarrow \mathrm{Fe}^{3+}+\mathrm{OH}^{-}
\end{gathered}
$$

$$
\begin{gathered}
\mathrm{OH}^{\mathrm{o}}+\mathrm{H}_{2} \mathrm{O}_{2} \rightarrow \mathrm{H}_{2} \mathrm{O}+\mathrm{HO}_{2}^{\mathrm{o}}, \\
\mathrm{Fe}^{2+}+\mathrm{HO}_{2}^{\mathrm{o}} \rightarrow \mathrm{Fe}^{3+}+\mathrm{HO}_{2}^{-} .
\end{gathered}
$$

Окисно-відновні реакції можуть бути ініційовані не тільки металами змінної валентності, а й органічними сполуками.

Як зазначалось вище, радикали можуть утворюватись не лише за рахунок присутності пероксиду водню. Утворення таких радикалів як супероксидний радикал $\mathrm{O}^{2-}$ та пероксид $\mathrm{O}_{2}^{2-}$ можуть призводити до утворення кисню, що теж може бути причиною підвищення величини $\mathrm{pH}$ розчину.

Під впливом кавітації також можуть відбуваються і інші реакції, що можуть впливати на величину $\mathrm{pH}$, зокрема, також спостерігалось підвищення вмісту нітратів при обробці води способом ДІВЕ в присутності повітря. Таким чином, використання способу ДІВЕ для ініціювання реакцій утворення радикалів та прискорення перебігу окисно-відновних реакцій у водних розчинах дозволить знайти його нове застосування в області нейтралізації кислих розчинів.

\section{Висновки}

Нейтралізація кислих стічних вод за допомогою кавітаційних процесів - це новий, перспективний метод, який потребує поглибленого вивчення механізмів кавітаційного впливу на оброблюване середовище під час перебігу процесу нейтралізації з метою вибору оптимальних технологічних i конструктивних параметрів i може знайти широке промислове використання.

Продовження експериментальних досліджень в даному напрямку 3 кислотними і лужними розчинами різної концентрації дозволить отримати нові результати, які допоможуть детальніше вивчити механізм перебігу процесу і визначати оптимальні режимні параметри для його проведення. Розуміння механізму перебігу процесу також дасть змогу знайти нові напрямки його використання в різних галузях промисловості і народного господарства.

\section{ЛІТЕРАТУРА}

1. Фізико-хімічні основи технології очищення стічних вод : Підруч. для студ. хім.-технол. і екол. спец. вищ. закл. освіти / А. К. Запольський, Н. А. 
Мішкова-Клименко, І. М. Астрелін, М. Т. Брик, П. І. Гвоздяк, Т. В. Князькова. - К. : Лібра, 2000. $-552 \mathrm{c}$.

2. Водоотведение и очистка сточных вод [Текст] : учеб / С. В. Яковлев, Ю. В. Воронов. - М. : Изд-во Ассоциации строительных вузов, 2002. $-704 \mathrm{c}$.

3. Долінський А.А. Принцип ДІВЕ та його використання у технологічних процесах. - К.: Наукова думка - 2001. - 346 с.

4. Рождественский В.В. Кавитация. - Л.: Судостроение, 1977. - 248 с.

5. Мокрый Е.Н., Старчевский В.Л. Ультразвук в процессах окисления органических соединений. - Львов: Вища шк. Изд-во при Львов унте. $-1987 .-120$ c.
6. Роменский А.В., Казаков В.В., Гринь Г.И и др. Ультразвук в гетерогенном катализе - X.: Cеверодонецк, 2006. - 270 с.

7. Маргулис М.A. Основы звукохимии (химические реакции в акустических полях): Учеб. пособие для хим. и хим.-технол. спец. вузов. - М.: Высш. шк., 1984. - 272 с.

8. Косенко В. А. Изменение водородного показателя в искусственно изолированных природных водах [Електронний ресурс] / В. А. Косенко, Ю. Е. Никитин. // Учёные записки Новгородского университета. - 1999. - Режим доступу до ресурcy: http://www.admin.novsu.ac.ru/uni/scpapers.nsf/ 319f85f85d57590bc3256744002dc9dd/519e7f12ab $\underline{65963 \mathrm{ac} 3256775001 \mathrm{fbc} 4 \mathrm{e} \text { !OpenDocument. }}$ 


\section{USING PROSPECT METHOD OF DISCRETE-PULSE INPUT OF ENERGY TO NEUTRALIZING ACIDIC AQUEOUS SOLUTIONS}

\section{Yarotskyi S. ${ }^{1}$, Tselen B. ${ }^{2}$.}

${ }^{1}$ Institute of Engineering Thermophysics of the National Academy of Sciences of Ukraine, st. Zhelyabova, 2a, Kyiv, 03680, Ukraine

${ }^{2}$ National technical university of Ukraine "Kyiv polytechnic institute", Prospect Peremohy, 03056, Kyiv, Ukraine

Efficiency of discrete-pulse input of energy effect to aqueous solutions was validated. Mechanism of water radical decay and hydrogen peroxide formation under cavitation effect, the role of bicarbonates and iron ions contained in water to change its $\mathrm{pH}$ were considered. New ways using discrete-pulse input of energy from rotor-pulsation apparatus type such as rotor-stator-rotor were offered. Acidic wastewater neutralization using cavitation process is a new promising method that requires in-depth study of cavitation impact mechanisms on the work environment during the neutralization of the process to select the optimal technological and structural parameters and can be widely industrial use. Continued experimental research in this area with acid and alkaline solutions of various concentrations will provide new results that help to learn more about the process mechanism and determine the optimum parameters. Understanding the process mechanism will help to find new areas of use in various industries and economy.

References 7, Tabl. 1, Fig 1.

Key words: cavitation, discrete-pulse input of energy, neutralization, aqueous solutions, hydrogen peroxide, bicarbonates.

1. Zapolskyi, A., Mishkova-Klymenko, N., Astrelin, I., Bryk, M., Gvozdiak, P., Kniazkova, T. (2000). Fizyko-khimichni osnovy tekhnolohii ochyshchennia stichnykh vod [Physico-chemical fundamentals of wastewater treatment]. Kyiv, Ukraine: Libra, 552 p. (Ukr.)

2. Yakovlev, S., Voronov, Y. (2002). Vodootvedenie i ochistka stochnyh vod [Sewerage and wastewater treatment]. Moscow, Russia: Association building schools, 704 p. (Rus.)

3. Dolinskyi, A. (2001) Pryntsyp DIVE ta yoho vykorystannia $\mathrm{u}$ tekhnolohichnykh protsesakh [Fundamental of discrete-pulse input of energy and its application in technological processes]. Kyiv, Ukraine: Naukova dumka, 346 p. (Ukr.)

4. Rozhdestvenskyi, V. (1977). Kavitaciia [Cavitation]. Saint Petersburg, USSR: Shipbuilding, 248 p. (Rus.)

5. Mokryi, E., Starchevskyi, V. (1987). Ultrazvuk $\mathrm{v}$ protsessah okisleniia organicheskih soedinenii [Ultrasound in the organic compounds oxidation]. Lviv, USSR: Vyshcha shkola, 120 p. (Rus.)

6. Romenskii, A., Kazakov V., Grin G. (2006). Ultrazvuk $\mathrm{V}$ geterogennom katalize [Ultrasound in the heterogeneous catalysis]. Kharkiv, Ukraine: Severodonetsk, 270 p. (Rus.)

7. Margulis, M. (1984) Osnovy zvukohimii (himicheskie reaktsii v akusticheskih poliah) [Basics Sonochemistry (chemical reactions in the acoustic fields)]. Moscow, USSR: Vyshcha shkola, 272 p. (Rus.)

8. Kosenko, V., Nikitin, Y. (1999) Izmeneniie vodorodnogo pokazatelia $\mathrm{V}$ iskusstvenno izolirovannykh prirodnykh vodakh [Changing $\mathrm{pH}$ in isolated natural waters]. Uchonyye zapiski Nizhegorodskogo universiteta. . Retrieved from http://www.admin.novsu.ac.ru/uni/scpapers.nsf/319f 85f85d57590bc3256744002dc9dd/519e7f12ab6596 3ac3256775001fbc4e! OpenDocument. (Rus.)

Получено 17.04.2015 Received 17.04.2015 